\title{
The Effect of Binding Types on the Biomass Briquette Calorific Value from Cow Manure as a Solid Energy Source
}

\author{
Amanda Anatasya ${ }^{1, *}$, Ngurah Ayu Ketut Umiati $^{1}$, and Agus Subagio ${ }^{1}$ \\ ${ }^{1}$ Physics Department, Faculty of Science and Mathematics, Diponegoro University, Semarang - Indonesia
}

\begin{abstract}
Biomass briquettes have been made as an alternative energy source from cow dung waste. Molasses and starch were used as binder material with a carbonization temperature of $400{ }^{\circ} \mathrm{C}$ for 2 hours. The work aims to produce biomass briquettes with the best heating value based on analysis of composition effect and type of binder on the briquette with calorific value. The heat test results showed that briquettes with $10 \%$ sugar cane binding content produced the highest calorific value of 3907.5 calories/gram. Sugar cane drops become the better binder than starch in biomass briquettes production.
\end{abstract}

Keywords: Biomass briquettes; sugar cane drops; starch; calorific value.

\section{Introduction}

Biomass is a promising alternative energy source to develop. Conventionally, biomass is natural material garbage, but it can be processed into a source of energy in the form of biomass briquettes. Biomass briquettes are fuels with a high level of heating value and it can be used in everyday life [1].

Cow manure is one of the biomasses that can be used as an alternative energy source. Cow manure as organic waste is obtained from the livestock industry and it will be harmful to the environment if it is not managed properly. Nitrogen $(\mathrm{N})$ and phosphorus $(\mathrm{P})$ concentrations found in cow dung cause nutritional imbalances and pollution in the environment [2]. However, if cow manure is reused in good management, then it will become an appropriate alternative energy source as a substitute for fossil fuels. Cow manure can produce a heat of around 4000 calories/gram and high methane gas (CH4). Methane gas has the main function as an ignition gas in briquettes to make the flammable briquettes [3]. In previous work, briquettes were made from a mixture of cow dung and agricultural waste by using the carbonization method $[3,4]$. Other work makes briquettes from a mixture of cow dung and water hyacinth [5]. Briquettes were also made from a mixture of cow dung and sawdust [6].

The carbonization method is also alternative method biomass briquettes production. During carbonization process, the temperatures reached $500^{\circ} \mathrm{C}$ up to $600{ }^{\circ} \mathrm{C}$ in the manufacturing biomass briquettes from oil palm shell waste and rubber seed shells [7]. Other work applied a carbonization temperature from $300^{\circ} \mathrm{C}$ up to $400^{\circ} \mathrm{C}$ as the briquettes made from teak leaves [8].

In addition to the carbonization method, the ratio of composition and type of binder become a significant influence in biomass briquettes production. The binding agent is required to produce a compact briquette. A good raw material for briquette adhesives has a good cohesion force when it is mixed with semi-cocas or coal. This raw material must be flammable, not smoky, available in large quantities, cheaper price, no odors emission, non-toxic and harmless [8]. Sugarcane drops and starch are the promising binders in biomass briquettes production because they have the characteristics above. In other work, the bio-briquettes were made from bottom ash materials which were taken from waste steam power plants by using coffee shell biomass with the variation of binding substances such as sugar cane and starch [9]. In addition, the use of sugar cane drops was also carried in making biomass briquettes from a mixture of peanuts and cashew nut waste [10].

The work on this paper focuses on the effect binder type on the heating value of biomass briquettes made from cow dung waste as a solid energy source. The work aims to obtain cow dung biomass briquettes with a higher heating value by analyzing the effect of composition and type of binder. Several parameters involved in these biomass briquettes are heating values, water content, ash content, volatile matter content, and fixed carbon content produced from burning briquettes. This study uses adhesive starch and molasses. The type of binder is chosen by considering the easiness to obtain raw materials, high adhesion, odorless, non-toxic, harmless, and no excessive smokes.

In making cow dung powder, a sieve with 50 mesh is applied. The carbonization process is carried out at a temperature of $400{ }^{\circ} \mathrm{C}$ for 2 hours. Variations in the composition of cane drops by $10 \%, 15 \%, 20 \%, 25 \%$ and starch by $10 \%, 15 \%, 20 \%, 25 \%$.

*Corresponding author: amandatampubolon.2015@,fisika.fsm.undip.ac.id 


\section{Methodology}

\subsection{Biomass Briquettes Production Process}

The production process in cow dung biomass briquettes begins with drying cow dung in the sun for 24 hours so that the water content is low. The dried cow manure is mashed using mortars and pestles to obtain a finer powder. The mashed cow manure is sifted using a 50mesh sieve in order that the cow manure with a size of bigger than 50 mesh is eliminated. The sieved cow manure is put into a crucible device and it is carbonized using a furnace with a temperature of $400{ }^{\circ} \mathrm{C}$ for 2 hours. The heating process starts from the lowest temperature at $30{ }^{\circ} \mathrm{C}$ and the temperature is adjusted to rise from $30{ }^{\circ} \mathrm{C}$ to $400{ }^{\circ} \mathrm{C}$ in 13 minutes.

The briquettes process production requires a binder to make formation and solid briquettes. In this work, the binder was starch and sugar cane. A composition ratio is $\mathrm{x}$ cow manure: $\mathrm{y}$ Binder: $\mathrm{z} \mathrm{H} 2 \mathrm{O}$ with a ratio of $\mathrm{y}$ and $\mathrm{z}$ is 1: 1. Variations in the number of binders are $10 \mathrm{wt} \%, 15$ $\mathrm{wt} \%, 20 \mathrm{wt} \%$, and $25 \mathrm{wt} \%$ of the mass of cow dung to obtain 8 different briquette types.

After carbonized briquettes are mixed with a binder, it is inserted into the printed form and pressed by using a hydraulic jack. The printed sample is then put into the oven for the drying process for 3 hours with a temperature of $100{ }^{\circ} \mathrm{C}$.

After the briquettes are dried, the physical properties of briquettes are investigated through several tests. Calorific value (calories/gram), water content $(\%)$, ash content $(\%)$, volatile matter $(\%)$, and fixed carbon $(\%)$ are the observed parameters in cow dung briquette testing. Testing heat values is applied by using a bomb calorimeter. Testing of moisture content, ash content, and the volatile matter is carried out by using a furnace. Fixed carbon is obtained through the following calculations [2]:

$$
F C=100-\% \text { of }(V M+A C)
$$

$\mathrm{FC}=$ Fixed Carbon (\%), $\mathrm{VM}=$ Volatile matter $(\%), \mathrm{AC}=$ ash level (\%).

\subsection{Research Flow Diagram}

Figure 1 describes the research steps in the form of a research flow diagram.

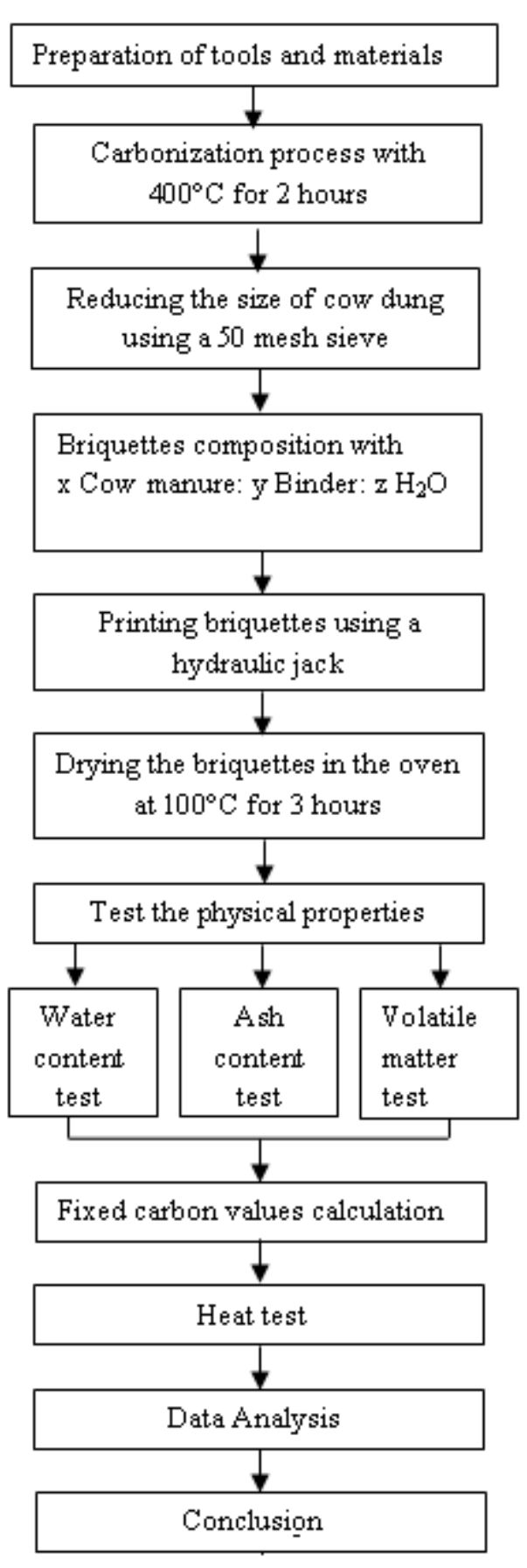

Fig. 1. Research flow diagram

\section{Results and Discussion}

Cow manure biomass briquettes have been successfully made by using the carbonization method and pressing techniques. The carbonization process causes a decrease in the mass of cow dung from 800 grams to 483 grams and color differences in cow dung, as can be seen in Figure 2. 


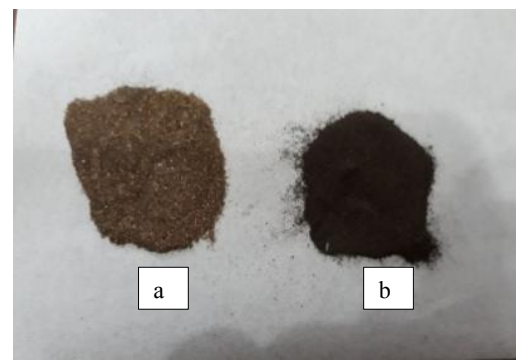

Fig. 2. Cow manure powder (a) Before carbonization, (b) After carbonization

After the carbonization process, briquette printing is carried out by using a printing press and hydraulic jack. Briquettes that use starch binders are more easily broken and less dense when it is compared to briquettes from sugar cane drops. Briquettes with flour binder produce a lot of black powder. In addition, the binding composition also affects the density of briquettes. The greater the mass percent (wt $\%$ ) of the binder used, the stronger and denser briquettes. Based on Figure 3 and Figure 4, it can be seen that the binder with a content of $25 \%$ produces less than black powder.

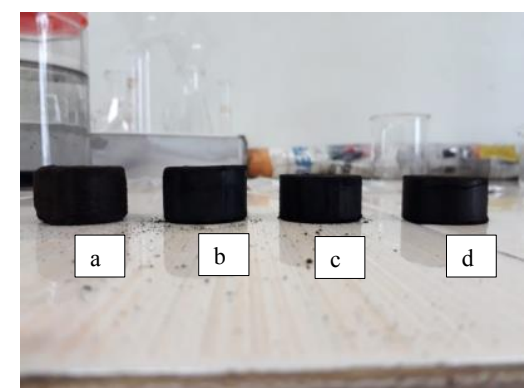

Fig. 3. Biomass briquettes with cow dung with starch binder (a) $10 \%$ starch, (b) $15 \%$ starch, (c) $20 \%$ starch (d) $25 \%$ starch

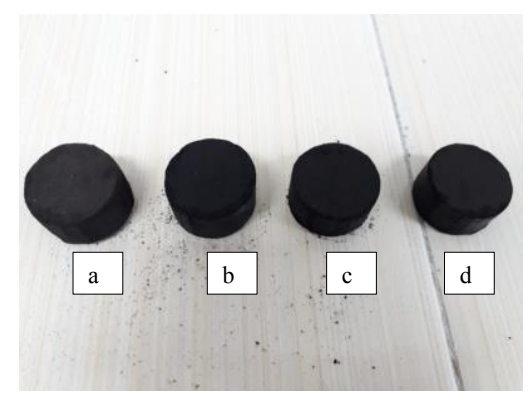

Fig. 4. Biomass briquettes with cow dung with cane drops (a) $10 \%$ sugar cane drops, (b) 15\% sugar cane drops, (c) Sugarcane drops $20 \%$ (d) Sugarcane drops $25 \%$

After the printing process is complete, the briquettes are heated in the oven for 3 hours to reduce the water content. High water content reduces the heat value so the briquettes need to be warmed up. Briquettes with sugar cane drops have a more significant decrease in mass after heating process when it is compared to briquettes using starch binders. The decrease in mass occurs because molasses are liquid so the water content inside this type of briquettes is higher. During the heating process, the water content inside the briquette decreases and the briquette mass decreases too. The change in the mass of briquettes is shown in Table 1.

Table 1. Change in the Briquette Mass Before and After Heating

\begin{tabular}{|c|c|c|}
\hline Variation & $\begin{array}{c}\text { Mass Before } \\
\text { Heating }(\mathrm{g})\end{array}$ & $\begin{array}{c}\text { Mass After } \\
\text { Heating }(\mathrm{g})\end{array}$ \\
\hline Sugar cane 10\% & 14,3 & 12,8 \\
\hline Sugar cane $15 \%$ & 15,7 & 13,3 \\
\hline Sugar cane $20 \%$ & 16,2 & 13,4 \\
\hline Sugar cane 25\% & 16,9 & 14,2 \\
\hline Starch 10\% & 12,0 & 11,8 \\
\hline Starch 15\% & 12,6 & 11,9 \\
\hline Starch $20 \%$ & 13,9 & 13,1 \\
\hline Starch $25 \%$ & 14,4 & 13,8 \\
\hline
\end{tabular}

The calorific value produced in biomass briquettes is determined by conducting a combustion test using a bomb calorimeter. Calorific value is the most important parameter in determining the quality of briquettes. The higher the calorific value of a briquette, the better the quality as it can be seen in Fig. 5 .

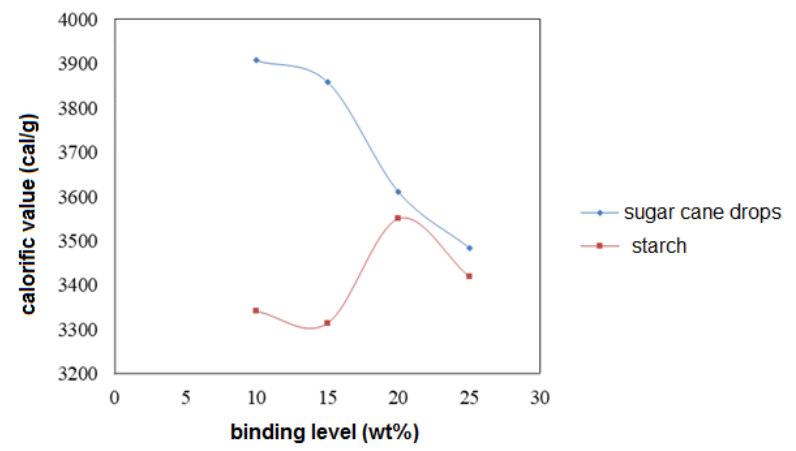

Fig. 5. Calorific value of the briquette from sugarcane drop and starch

Based on the graph in the Fig. 5, briquettes with $10 \%$ sugar cane binder are the best quality briquettes because they produce the highest calorific value of $3907.5 \mathrm{cal} / \mathrm{g}$. Briquettes with a binding content of $15 \%$ starch are the worst quality briquettes because they produce the lowest heating value of $3314.3 \mathrm{cal} / \mathrm{g}$.

The level of volatile matter produced by the cane and starch is shown in Fig. 6.

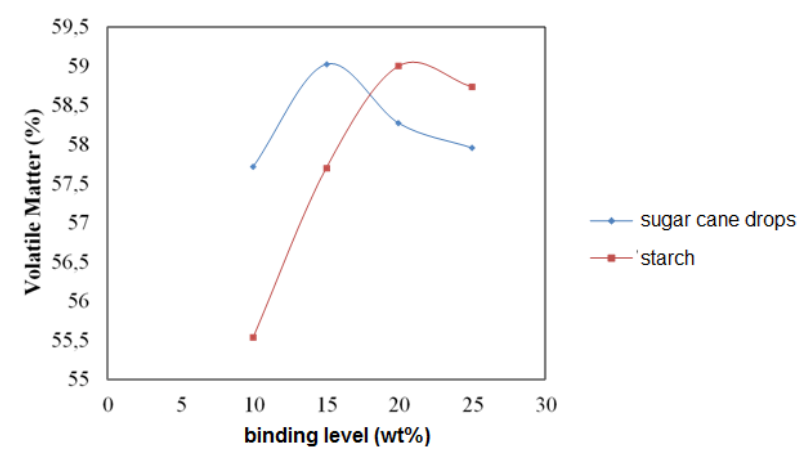

Fig. 6. Volatile matter of the briquette from sugarcane drop and starch 
The water content produced by the cane drops and starch is shown in Fig. 7.

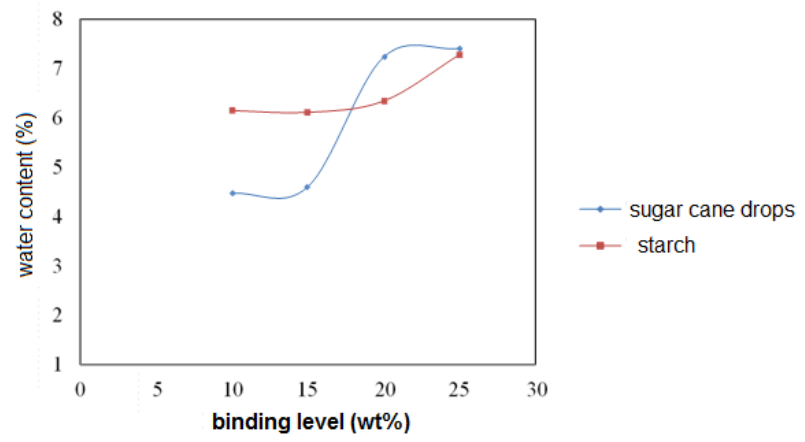

Fig. 7. Water content of the briquette from sugarcane drop and starch

The ash content produced by the cane drops and starch is illustrated in Fig. 8.

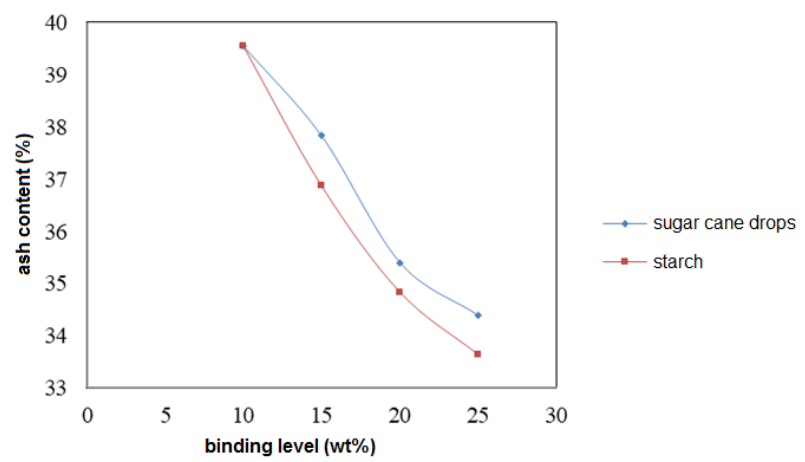

Fig. 8. Ash content of the briquette from sugarcane drop and starch

The level of fixed carbon produced by the cane drops and starch is shown in Figure 9.

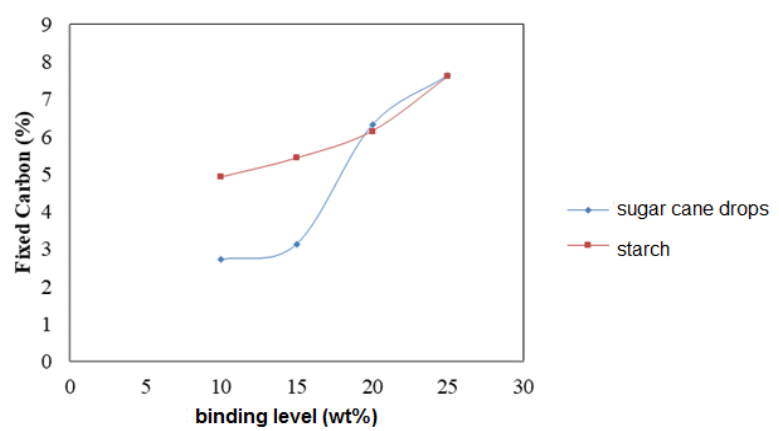

Fig. 9. Fixed carbon of the briquette from sugarcane drop and starch

The optimum value is taken based on the results of the heat test by considering the results of moisture content, ash content, volatile matter, and fixed carbon. Briquettes with the highest calorific value are briquettes with the most optimum value because the calorific value is the main factor for the quality of a briquette so, in this work, briquettes with $10 \%$ sugar cane drops are the best briquettes. The overall test results can be seen in Table 2 .
Table 2. Briquette test results

\begin{tabular}{|l|c|c|c|c|c|}
\hline $\begin{array}{l}\text { Variat } \\
\text { ion }\end{array}$ & $\begin{array}{c}\text { Calor } \\
\text { Value } \\
\text { (cal/g) }\end{array}$ & $\begin{array}{c}\text { Wat } \\
\text { er } \\
(\%)\end{array}$ & $\begin{array}{c}\text { Ash } \\
(\%)\end{array}$ & $\begin{array}{c}\text { VM } \\
(\%)\end{array}$ & $\begin{array}{c}\text { FC } \\
(\%)\end{array}$ \\
\hline $\begin{array}{l}\text { Sugar } \\
\text { cane } \\
10 \%\end{array}$ & 3907.5 & 4.48 & 39.55 & 57.72 & 2.73 \\
\hline $\begin{array}{l}\text { Sugar } \\
\text { cane } \\
15 \%\end{array}$ & 3859.4 & 4.60 & 37.83 & 59.03 & 3.15 \\
\hline $\begin{array}{l}\text { Sugar } \\
\text { cane } \\
20 \%\end{array}$ & 3610.6 & 7.24 & 35.40 & 58.27 & 6.33 \\
\hline $\begin{array}{l}\text { Sugar } \\
\text { cane } \\
25 \%\end{array}$ & 3484,0 & 7.41 & 34.39 & 57.96 & 7.66 \\
\hline $\begin{array}{l}\text { Starch } \\
10 \%\end{array}$ & 3341.4 & 6.15 & 39.55 & 55.54 & 4.92 \\
\hline $\begin{array}{l}\text { Starch } \\
15 \%\end{array}$ & 3314.3 & 6.12 & 36.87 & 57.70 & 5.43 \\
\hline $\begin{array}{l}\text { Starch } \\
20 \%\end{array}$ & 3550.6 & 6.34 & 34.84 & 59.01 & 6.15 \\
\hline $\begin{array}{l}\text { Starch } \\
25 \%\end{array}$ & 3418.6 & 7.28 & 33.65 & 58.74 & 7.62 \\
\hline
\end{tabular}

\section{Conclusion}

The work gives several highlights as conclusions. Biomass briquette for cow manure is successfully made by using the carbonization method at $400^{\circ} \mathrm{C}$ for 2 hours. Calorific value is the main parameter in briquettes production and the optimal value is produced by briquettes with $10 \%$ sugar cane binding as it produces the largest calorific value of $3907.5 \mathrm{cal} / \mathrm{g}$.

\section{References}

1. G.D. Zupančič, M. Panjičko, B. Zelić, Biogas Production from Brewer's Yeast Using an Anaerobic Sequencing Batch Reactor, Food Technol. Biotechnol. 55(2), 187 (2017)

2. P. Abdeshahian, J.S. Lim, W.S. Ho, H. Hashim, C.T. Lee, Potential of Biogas Production from Farm Animal Waste in Malaysia, Renewable and Sustainable Energy Reviews 60, 715 (2016)

3. Santosa, Mislaini, S.P. Anugrah, Studi Variasi Komposisi Bahan Penyusun Briket dari Kotoran Sapi dan Limbah Pertanian, Organisasi Profesi Ilmiah (OPI) LIPI, 2 (2010)

4. D. Tampubolon, Pembuatan Briket Arang dari Kotoran Sapi Perah dengan Penambahan Tempurung Kelapa, Skripsi Jurusan Ilmu Produksi Ternak Fakultas Peternakan Institut Pertanian Bogor (2001)

5. W. Bandara, P. Kowshayini, Evaluation of the Performances of Biomass Briquettes Produced with Invasive Eichornia crassipes (Water hyacinth), Wood Residues and Cow Dung for Small and Medium Scale Industries, Journal of Fundamentals of Renewable Energy and Applications 8(1), 1 (2017) 
6. K. Sivakumar, B. Sivaraman, N.K. Mohan, Effectiveness of Briquetting Bio Mass Materials with Different Ratios in $10 \mathrm{~kW}$ Down Draft Gasifier, International Journal of Engineering Science and Technology (IJEST) 3(11), 7959 (2011)

7. R. Moeksin, A.A. Pratama, D.R. Tyani, Pembuatan Briket Bioarang dari Campuran Limbah Tempurung Kelapa Sawit dan Cangkang Biji Karet, Jurnal Teknik Kimia 23(3), 147 (2017)

8. M. Yusuf, D.E. Fajrin, Pembuatan Briket Arang dari Daun Jati dengan Sagu Aren sebagai Pengikat, Jurnal Teknik Kimia 17(1), 34-37 (2010)

9. B. Gunawan, S. Slamet, A. Syahroni, Perbandingan Nilai Kalor Biobriket yang Terbuat dari Bottom Ash Limbah PLTU dan Biomassa Cangkang Kopi dengan Variasi Komposisi dan Jenis Pengikat yang Berbeda, TEKNIK, p-ISSN 0852-1697, e-ISSN: 2460-9919 36(2), 81 (2015)

10. T. Wijayanti, Pembuatan Biobriket dari Campuran Limbah Kacang Tanah dan Limbah Kacang Mete Menggunakan Perekat Tetes Tebu, Jurnal Pendidikan Teknik Mesin, 1(1), 1 (2012) 